УДК 327 (073 : 470)

DOI: 10.26693/ahpsxxi2019.01.126

\title{
РОСІЯ В КОНТЕКСТІ ЗОВНІШНЬОПОЛІТИЧНОЇ СТРАТЕГІЇ США: ПОЛІТИКО-ДЕСКРИПТИВНИЙ АНАЛІЗ ПОСТБІПОЛЯРНИХ ЧАСІВ
}

\author{
Ірина Дудко, \\ e-mail:idudko@hotmail.com \\ ORCID: https://orcid.org/oooo-ooo2-8881-8274 \\ Національна академія державного управління \\ при Президентові Украӥни, \\ Україна, о4о5о, м. Київ, вул. Академіка Ромоданова, 12/2
}

Стаття орієнтована на політико-дескриптивний аналіз зовнішнъополітичного курсу США періоду постбіполярних часів. Серед проблем в колі дискусї - фактори, що зумовлювали особливу увагу американського керівництва до Росї̈ від початку постбіполярного світу, а також еволюцію стратегічних підходів США щзодо Росї впродовж 1990-2010-х рр., включаючи військову агресію РФ проти Грузї (2008) і Украӥни (2014-2020) як етапів формування сучасного стану відносин по лінї̈ США - РФ.

Ключові слова: зовнішнъополітична стратегія США, Росія, протиріччя

Постановка проблеми. Оцінюючи значення Росії в зовнішньополітичній стратегії США за постбіполярні часи, відомий американський політик і науковець, колишня радниця з питань національної безпеки і Держсекретар за часи Дж. Буша-молодшого К. Райс писала: «Сполучені Штати мають визнати, що Росія як велика держава завжди перебуватиме в колі їхніх інтересів, які конфліктують, так само як і поєднуються». Такий підхід базувався на статусі Росії як ядерної держави і члена РБ ООН, що, попри усі негаразди внутрішнього розвитку, і насамперед у вимірі демократії, зберігала вплив на систему міжнародних відносин, а за цим зумовлювала лінію на потенційне партнерство по лінії США - Росія. Втім, саме впливи Росії на міжнародні відносини, що відображали переважно імперські претензії останньої, становили загрозу світовому статус-кво всупереч позиції США, що викликало лінію на суперництво сторін.

Так, період постбіполярних часів не виявив послідовної зовнішньополітичної стратегії США по відношенню до Росії як тенденції, що відзначала характер відносин - від суперництва до спроб партнерської взаємодії сторін і навпаки. Наростання імперської політики Росії, найбільш драматичним проявом чого стала агресія РФ проти Грузії i, насамкінець, України, зумовили готовність американської адміністрації на відверте протистояння Росії. Втім, мова може йти не просто про підтримку Грузії і України як країн, орієнтованих на демократію (відповідно проголошеної від початку 1990-х рр. стратегії США), а про політику більш глобального рівня з розподілом геополітичних сфер впливу Росії і США. Аналітичний розгляд в цьому відношенні процесу формування зовнішньополітичної стратегії Сполучених Штатів по відношенню до РФ з урахуванням специфіки постбіполярного світу може слугувати підгрунтям оцінки ключових позицій сучасних міжнародних відносин, де на порядку денному питання не тільки національної (на рівні окремих країн), а й регіональної і навіть глобальної безпеки сучасного світу.

Стан наукової розробки. Стратегія США щодо Росії перетворилась за постбіполярні часи на один з найбільш активно досліджуваних напрямів сучасної, i насам-

\footnotetext{
${ }^{1}$ Rice, C. (2000). Life after the Cold War. Campaign 2000: Promoting the National Interest. Foreign Affairs, 79, (1), 45-62. Retrieved from https://www.foreignaffairs.com/articles/2000-0101/campaign-2000-promoting-national-interest
} 
кінець, американської політичної науки. Серед основоположників теми ще протягом 1990-х рр. - такі видатні представники американської політичної думки як У. Ростоу, Г. Кіссінджер, 3. Бжезинський, Р.Н. Хаасс, С. Хантінгтон, Дж. Гудбі й інші, що заклали підвалини об'єктивістським підходам до сприйняття й аналізу сучасних міжнародних відносин, зокрема, у вимірі зовнішньої політики США щодо Росії.

Протягом 2000-х і 2010-х рр. до кола дослідників теми долучилось широке коле нового покоління науковців - представників західної, насамперед, американської політологічних шкіл. Так, внесок західних дослідників до різних аспектів зовнішньополітичної стратегії США до РФ тільки протягом останніх декількох років склав надзвичайний обсяг робіт, включно 3 доробком таких авторів, як П. Стронскі (P. Stronski), Р. Сокольський (R. Sokolsky); M. Кеннеді (M. Kennedy); Дж. Гурганус (J. Gurganus), Ю. Румер (Е. Rumer); Ф. Брідлав (Ph. Breedlove), Е. Фаркас (Е. Farkas), Д. Фрід (D. Fried), М. Нойбургер (M. Neuburger); Ш. Уолкер (Sh. Walker); Ф. Хілл (F. Hill); Д. Xappic (D. Harris); Д. А. Шлапак (D. A. Shlapak), M. Джонсон (M. Johnson); Ст. М. Уолт (St. M. Walt), Х. Уайт (H. White); M. Рапп-Хупер (M. Rapp-Hooper), Р. Фрідман Лісснер (R. Friedman Lissner); А. Гольц (A. Golts), М. Кофман (M. Kofman); Б. Талант (B. Talant); К. Джайлс (K. Giles); У. Кун (U. Kuhn); H. Хayep (N. Hauer); А. Лун (А. Luhn), Д. Ніколс (D. Nicholls); Дж. Блан (J. Blanc), Е. Вайс (A. Weiss); К. Міллер (Ch. Miller), Е. Хейл (A. Heil), В. Гроєц (W. Grojec); Д.Е. Сангер, (D.E. Sanger); А. Лунд (A. Lund); Е. Шмітт (Е. Schmitt), інших, орієнтованих на врахування новітніх тенденцій міжнародних відносин постбіполярних часів.

Окремий напрям робіт при цьому протягом постбіполярного періоду склали напрацювання вітчизняних вчених - Б. Гончара, О. Гавриша, А. Дашкевича, М. Дорошка, О. Їжака, Є. Камінського, Б. Канцелярука, О. Кондратенка, Д. Лакішика, В. Орлик, І. Погорської, М. Рижкова, О. Сушка, Н. Турчак, С. Федуняка, М. Фесенка, А. Худолія, О. Шевчука, С. Шергіна, багатьох інших, що (з урахуванням регіональної специфіки підходів до розгляду теми) суттєво додали до формування об’єктивістських підходів аналізу зовнішньополітичної стратегії США щодо РФ. Втім тема не може вважатись остаточно висвітленою як з урахуванням потреби узагальнення вже накопиченого матеріалу, так і його поглиблення з огляду на поточні особливості міжнародних відносин (та ролі в них США і Росіі) як регіонального, так і глобального рівня.

Метою статті $\epsilon$ політико-дескриптивний аналіз зовнішньополітичної стратегії США та її еволюції періоду постбіполярних часів щодо Росії; визначення специфіки підходів американського зовнішньополітичного істеблішменту до РФ в умовах агресії останньої на теренах СНД, включно з позицією в цьому відношенні адміністрацій Б. Обами і Д. Трампа.

Викладення основного матеріалу. Російський напрям посів основоположне місце в зовнішньополітичній стратегї США від періоду постбіполярних часів. Втім мова може йти не тільки про вагоме, а й значною мірою одновимірне сприйняття Росії як єдино цілісного представника усього пострадянського регіону від початку 1990-х pp.

Дана тенденція пояснювалась низкою чинників, серед яких, зокрема, неготовність американського політикуму до формування зовнішньополітичного курсу до кожної пострадянської країни після розвалу СРСР. Незнання реальної ситуації послаблювало б позиції США на пострадянському просторі і, як наслідок, звужувало б можливості реалізації декларованої вирішальної ролі у міжнародних відносинах ${ }^{2}$ Ситуація на теренах $\mathrm{CHД} \mathrm{показувала} \mathrm{водночас} \mathrm{й} \mathrm{певну} \mathrm{орієнтованість} \mathrm{політикуму} \mathrm{нових} \mathrm{не-}$ російських незалежних держав підпорядкуватися Росії. Сприяння цим тенденціям відповідало новим російським елітам. Америка ж керувалася ідеєю демократизації Росії як базового чинника своєї стратегії на перспективу. Це мало б забезпечити демократизацію країн Співдружності, приборкати можливу російську агресію щодо

${ }^{2}$ Lynch, A. (1992). The Cold War is Over-Again. Boulder, San Francisco, Oxford: Westview Press, 159-166. 
них та унеможливити, як здавалось, громадянську війну, насильство, небажану міграцію і т. ін.3.

Вищезазначені позиції зумовлювались й ядерним статусом Росії та традицією їі присутності в глобальних справах, зокрема, у сфері нерозповсюдження ядерної зброї. Ця проблема загострилася у зв'язку з перспективою появи від початку 1990-х рр. поряд з Росією ще трьох ядерних держав - України, Білорусі та Казахстану, що тлумачилось у вимірі реальної загрози національній безпеці й інтересам США4.

Розвиток історичних подій, втім, вимагав коригування зовнішньополітичного курсу Сполучених Штатів по відношенню до пострадянського простору, включно з Росією, що - на противагу очікуваним демократизаційним впливам - відзначилась внутрішньою нестабільністю, активізацією націоналістичних сил у межах суспільства, зростанням зовнішніх неімперських геополітичних претензій до країн ближнього зарубіжжя. Зворотною до цього тенденцією з боку окремих держав-членів СНД стало прагнення зменшити залежність від Росії як геополітичного центру, і зокрема на засадах стратегічного партнерства зі Сполученими Штатами.

Останнє стосувалося передусім України, яка, відмовившись під тиском РФ і США (поряд з Білоруссю та Казахстаном) від ядерної зброї, виявила орієнтири щодо активного співробітництва з євроатлантичними економічними та військово-політичними структурами. Від 1994 року (денуклеаризації України) за адміністрації Б. Клінтона українська держава - в колі спеціальних інтересів Сполучених Штатів, що змінюють свою позицію: від нейтралітету чи навіть політичного тиску до помітної політичної підтримки України.

Диференціація підходів, орієнтованих, однак, на різний ступінь взаємодії сторін, починає характеризувати політику США й щодо інших країн СНД. Показовими в цьому відношенні є матеріали слухань 3 проблем ННД (нових незалежних держав) у Комісії з міжнародних відносин конгресу США у березні 1997 р., де окреслення конкретизованого вектору зовнішньої політики Сполучених Штатів до РФ знайшло відображення поєднано із визначеними орієнтирами США щодо інших пострадянських держав, включаючи Україну та Грузію, або в узагальненішому вимірі Україну та держави Центральної Азії та Кавказу. Так, вагомість України у системі національних інтересів США подавалася в матеріалах слухань переважно з погляду геополітичних міркувань як процвітаючої і безпечної у перспективі країни, що «стане наріжним каменем стабільності в їі частині світу»5. Країни Центральної Азії та Кавказу розглядались у контексті енергетичних можливостей ННД, здатних «прискорити розробку регіональних ресурсів, диверсифікувати запаси світової енергї, зміцнити енергетичну безпеку Заходу, забезпечити американські комерційні інтереси»6.

Такі підходи, зрозуміло, не відображали всієї сукупності зовнішньополітичних орієнтирів США щодо країн СНД. I, водночас, вони ставали базовими з погляду американських національних інтересів та пріоритетів зовнішньої політики 1990-х - початку 2000-х рр. Щодо Росії у даному відношенні, то вона викликала найбільшу за-

\footnotetext{
3 Motyl, A.J. (1991). Totalitarian Collapse, Imperial Disintegration, and the Rise of the Soviet West: Implications for the West. In A.J. Motyl (Ed.), The Rise of Nations in the Soviet Union. American Foreign Policy and the Disintegration of the USSR (pp. 59-60). New York: Council of Foreign Relations Press; Newmann, W.W. (1993). History Accelerates: The Diplomacy of Cooperation and Fragmentation. In J.E. Goodby, \& B. Morel (Eds.), The Limited Partnership. Building a Russian-US Security Community (pp. 50-51). Oxford: Oxford University Press.

4 Hoffman, D. (1991, December 9). «Soviet Union as we've known it» is gone, Baker says. The Washington Post; Meyer, S.M. (1991, December 12). Hyping the Soviet Nuclear Peril. New York Times; Luers, W.H. (1992). Harmonizing U.S. and European Interests. In I.J. Lederer (Ed.), Western Approaches to Eastern Europe (p. 43). New York: Council on Foreign Relations Press.

5 Hearing before the Committee on International Relations. House of Representatives, 105-th. Congress, 1-st session. (1997, March 12). US Relations with Russia and the Newly Independent States. Washington: Gov. print. off.
}

${ }^{6}$ Ibid. 
цікавленість, як і найбільше занепокоєння Сполучених Штатів з огляду на комплекс викликів економічним і безпековим позиціям США в умовах постбіполярного світу.

Серед головних напрямків політики Сполучених Штатів щодо Росії, реалізація яких мала слугувати американським національним інтересам: підтримка стабільності в Росії як країні, що отримала у спадщину та продовжувала утримувати значний арсенал зброї масового знищення, перебуваючи при цьому на вельми важливому етапі трансформаційних змін; залучення Росії до реалізації американських безпекових пріоритетів, включаючи запобігання поширенню небезпечних технологій і зброї та стримування небезпечних режимів повсюдно у світі; забезпечення поваги з боку Росії до суверенітету її сусідів.

Так, безпекова домінанта робила Росію і пріоритетом і «викликом». Пріоритет визначався «атрибутами великої держави: значне населення, величезна територія, військовий потенціал». Виклики подавалися через нестабільність економічних реформ, олігархізм, порушення прав людини, в тому числі через активізацію повномасштабних воєнних дій Росії у Чечні, протидії політиці США в регіоні Перської затоки та на Балканах...

Головна ж незмінна величина, втім, на цей час залишалась на ниві пріоритету. Порівняльний аналіз дозволяє стверджувати про відсутність серйозних змін у цій позиції з приходом до Кремля спочатку В. Путіна (200о р.), а потім Д. Медведєва (2008 р.). На підтвердження - заяви новообраного президента США від республіканців Дж. Буша-молодшого напередодні першої міжнародної подорожі в червні 2001 р. щодо зацікавленості стратегічного партнерства з Росією7. Зазначене знайшло підтвердження й на всіх трьох російсько-американських самітах, які відбулись у Словенії (червень 2001 р.), Вашингтоні (листопад 2002 р.), Москві (травень 2002 р.), причому з урахуванням ідентичних позицій обох сторін. «Ми виходимо на рівень нових стратегічних відносин... Ми є партнерами і будемо співробітничати заради просування стабільності, безпеки, економічної інтеграції, спільної протидії глобальним викликам і сприяння в залагодженні регіональних конфліктів», - зазначалося у Спільній декларації В. Путіна і Дж. Буша про нові стратегічні відносини від 26 травня 2002 p. $^{8}$.

Взагалі, аж до 2006 року - етапу відвертого позиціонування Росії як світового центру сили - стратегічні позиції двох держав - принаймні декларативно - виглядали у вимірі стратегічного партнерства. Початково такі підходи мали геополітичний і геоекономічний інтерес, у рамках яких на початку XXI століття починає домінувати енергетична складова. «Росія багата на енергоресурси, - зазначав 2002 року Дж. Буш-молодший. - Світу потрібні ці ресурси. Вам, напевно, відомо, що у нас немалий інтерес до багатого на нафту Каспійського регіону, і ми маємо намір працювати зі своїми російськими друзями, з іншими дружніми нам державами, щоб видобувати ці настільки необхідні для світу ресурси»9. Зазначене було спеціально підтверджено й на енергетичному саміті Буш-Путін у Х’юстоні восени 2003 року.

Так, енергопроблема доволі суттєво стримувала Америку від гострого офіційного реагування на окремі аспекти внутрішньої і зовнішньої політики Росії від початку 2000-х років. 3 іншого боку, iї очевидна політизація Кремлем наприкінці 2005 року - на прикладі України - спричинила гостру реакцію Білого дому. Базовий ще від 1990-х років інтерес Америки до Росії та інших країн СНД, задіяних у видобутку та транспортуванні на Захід енергоносіїв, врешті, став підгрунтям фундаментального конфлікту інтересів щодо країн каспійського і кавказького регіонів та України.

\footnotetext{
7 Интервью Дж.Буша группе журналистов в Белом доме (2001, 14 июня). «Россия не является врагом США». Retrieved from http://news.bbc.co.uk/hi/russian/news.sid-13880oo/1388695 8 Администрация Президента России. (2002, 24-26 мая). Совместная декларация Президента В.В. Путина и Президента Дж. Буша о новых стратегических отношениях между Российской Федерацией и Соединенными Штатами Америки. Retrieved from http://www.president.kremlin.ru/summit8/s8-doc.2ru.html 9 Интервью Дж. Буша группе журналистов в Белом доме (2001, 14 июня)...
} 
В колі уваги на даному етапі й процеси демократизації на пострадянському простору. Так, кольорові революції: Роз в Грузії (2003р.) і Помаранчевої в Україні (2004 р.), поряд з Тюльпановою революцією в Киргизстані і спробою революції в Узбекистані в 2005 р., стали суттєвим етапом зростаючого протистояння США і РФ щодо впливів на ННД. Втім сутність проблеми полягала не тільки в процесах демократизації, а й в тенденціях неконтрольованого Росією економічного і навіть військового співробітництва Сполучених Штатів і країн СНД, де, поряд з Росією і Україною, особливе значення посіли країни Середньої Азії і Закавказзя.

Це проявилося найбілыш показово в умовах антитерористичної війни США, коли всебічна підтримка Білого дому з боку світової спільноти уможливила, принаймні на початковому етапі кампанії, не тільки більш тісні зв’язки Сполучених Штатів з Росією (до війни США в Іраку 2003 р.) та, своєю чергою, з Україною, а й формування на території Киргизстану і Узбекистану американських військових авіабаз та створення підвалин для стратегічного партнерства США з Таджикистаном, Грузією, Вірменією та АзербайджаHOM $^{10}$.

Останнє мало витоком вельми суперечливі наслідки в системі міжнародних відносин 2000-х рр. і першої половини 2010-х рр. - від доволі успішних спроб з боку РФ на витискування військової присутності США в регіоні пострадянської Середньої Азії після завершення гострої фази антитерористичної операції на Близькому Сході із закриттям військових авіабаз баз в Узбекистані (Карши-Ханабад, 2005 р.) і Киргизстані (Манас, 2009 р. $\left.{ }^{11}\right)$ та поширення інтеграційних процесів на Євразійському просторі під егідою Москви до відвертого тиску РФ на пострадянські країни з метою збереження визначених раніше сфер впливу. 3 іншої сторони, показовими стали спроби окремих країн поглиблювати стратегічні відносини зі Сполученими Штатами на противагу Росії.

Найбільш показовими в цьому відношенні стали Грузія і Україна, революційні процеси в яких привели до влади євроатлантично орієнтовані політичні сили, забезпечивши їм, зі свого боку, дипломатичну і політичну підтримку з боку США. 2005 p. керівництво обох країн проголосили своїм головним зовнішньополітичним пріоритетом інтеграцію з НАТО і ЄС, бувши зорієнтованими по тому на приєднання до ПДЧ на Бухарестському саміті НАТО 2008 р. Дж. Буш-молодший до кінця президентського строку залишався прихильником стратегічних відносин з Україною і Грузією, виміром чого вважалась інтеграція країн з НАТО як безпекової компоненти національних інтересів США в пострадянському регіоні.

Заслуговує на увагу водночас вельми стримана реакція Сполучених Штатів на акт відкритої агресії Росії проти атлантично-орієнтованої Грузії в серпні 2008 р., внаслідок чого країна втратила до 20\% своєї території, зазнала значних втрат з боку грузинського суспільства матеріального, людського і морального характеру. Так, Грузія, як зазначають аналітики, не стала червоною лінією, яка відмежувала стадію накопичення суперечностей США і Росії до відвертої конфронтаційності між ними, будучи обмеженою дипломатичним осудом дій РФ з наступним посередництвом щодо припинення гострої фази війни.

Розглядаючи позицію США в російсько-грузинському конфлікті, аналітики звертають увагу на різнопланові чинники - від активної залученості США (попри пострадянський простір) до інших регіонів - Афганістану, Іраку, Лівї як сфер глобальної війни з тероризмом до зацікавленості Сполучених Штатів у збереженні стабільних відносин з Росією задля розв'язання глобальних проблем, зокрема, у сфері контролю над озброєннями, а також підтримки інтересів США на Близькому Сході та в Перській затоці12. Серед чинників - й розкол серед західної спільноти щодо оцінок росій-

${ }^{10}$ Cornell, S.F. (2002). America in Eurasia: One Year After. Current History. A Journal of Contemporary World Affairs, 101 (657), 330-336; Maynes, Ch.W. (2003). America Discovers Central Asia. Foreign Affairs, 82 (2), 120-132.

${ }_{11}$ Остаточно база Манас була закрита $2014 \mathrm{p}$.

12 Cohen, A. \& Hamilton, R.E. (2011). The Russian Military and the Georgia war: Lessons and implications. Carlisle, Pennsylvania: Strategic Studies Institute. 
сько-грузинського конфлікту, коли країни Європи (Німеччина, Франція, Італія) були більше зацікавлені (через енергетичну залежність) підтримувати відносини з Росією, ніж протистояти їйй

Комплекс визначених чинників не можна сприймати водночас поза загальних змін зовнішньополітичної стратегії США - від наступальної однобічності задля глобального домінування в світі за республіканську адміністрацію Дж. Буша-молодшого до багатосторонності і підтримки глобального лідерства США з опорою на союзників та міжнародні організації за демократичну адміністрацію Б. Обами. Саме такі підходи знайшли ствердження в «Стратегії національної безпеки США» від 2010 р., де (серед кола інших проблем із традиційним визнанням водночас пріоритету підтримки «універсальних ліберальних цінностей повсюдно в світі») особливо акцентовано на союзницьких відносинах з партнерами, у тому числі з Росією як одного з «центрів впливу». І хоча в документі говорилось про підтримку «суверенітету і територіальної цілісності сусідів Росії» (без спеціального згадування Грузіі), «пошук стабільних, сутнісних, багатовимірних відносин з Росією на взаємовигідних інтересах» розглядалось в якості зовнішньополітичних орієнтирів Сполучених Штатів ${ }^{14}$.

Зазначене як підхід на «перезавантаження відносин з Росією» стало одним з вагомих показників ліберально орієнтованої зовнішньої політики адміністрації Б. Обами на початковому етапі президентства останнього - тенденції, що може пояснюватись об’єктивною потребою у пошуку партнерів для подолання наслідків світової економічної кризи 2008-2009 pр., з одного боку. А з іншого - пошуком оновлених підходів в реалізації зовнішньополітичного курсу за умов провальності одностороннього гегемонізму США часів Дж. Буша-молодшого.

Втім, навіть ліберальні тенденції зовнішньої політики США не виключали наявності представників жорсткої лінії в американському політикумі - як теоретиків, так і реальних політиків (Дж. Маккейн, 3. Бжезинський, Р. Холбрук), що вимагали політичного курсу на «стримування» Росії у відповідь на їі агресію на пострадянському просторі. «Росію, на їх думку, слід було розглядати як потенційного супротивника, що не заслуговує на довіру. I якщо США не задумаються над тим, як «адекватно» відповісти Москві, активно підтримавши своїх східноєвропейських союзників, то вони можуть зіштовхнутися із значно більш серйозними викликами»15.

Саме відповідне сталося 2014 р., коли - за умов масштабного демократизаційного піднесення в Україні як Революції Гідності - Москва, скориставшись послабленням державного управління, здійснила проти неї акт відкритої агресії з анексією частини території (Криму) та утворення псевдо-республік на Сході країни. Російськоукраїнський конфлікт як можлива передумова дестабілізації ситуації у східноєвропейському регіоні становив реальну загрозу національним інтересам США з погляду на реальність перерозподілу на користь Москви геополітичних впливів в Європі.

Втім подіям 2014 р. передував певний історичний період, який можна охарактеризувати, якщо не холодною війною, то, принаймні, холодним миром з накопиченням критичної маси суперечностей американо-російських відносин по всім основним напрямам їх реалізації. Йдеться, зокрема, про глобальну війну з тероризмом: від початкової взаємної участі обох держав в міжнародній антитерористичній коаліції (під егідою США) після 11.09.2001 р, коли Росія вважалась рівноправним членом коаліції (а контртерористична операція РФ у Чечні - складовою війни проти міжнародного

13 Національний інститут стратегічних досліджень. (2008, 14 серпня). Експертна дискусія «Російсъко-грузинський конфлікт: причини та наслідки для європейської безпеки». Retrieved from http://old.niss.gov.ua/Table/14080o8/stenograma.htm

${ }_{14}$ National Security Strategy Archive. (2010, May 27). National Security Strategy. Retrieved from http://nssarchive.us/national-security-strategy-2010/

15 Ялі, М. (2012). Російсько-американські взаємовідносини напередодні президентських виборів в РФ: підсумки «перезавантаження». Актуальні проблеми міжнародних відносин, 107 (II), 48. 
тероризму16), до виходу Росії з коаліції після вторгнення США в Ірак (2003 р.) з окресленням відверто антиамериканської позиції останньої та подальшого загострення суперечностей сторін щодо цілей та методів, правових засад боротьби з міжнародними терористичними мережами ${ }^{17}$.

Хоча адміністрація Обами виступила з позицій оновленого бачення проблеми протидії тероризму через обмеження сфери боротьби з Аль-Каїдою регіоном Афганістану та спробою більш активного залучення до міжнародної діяльності в цій сфері такого впливового світового гравця, як РФ - підходу, що на певний час інтенсифікував співробітництво сторін, тривалого відновлення коаліції, як і перспективного співробітництва РФ і США у зазначеному напрямі досягти не вдалося. В колі уваги експертів - протиріччя через поєднання боротьби з тероризмом з боку США із встановленням американських сфер в Центральній Азії та на Близькому Сході, стриманість американської адміністрації щодо демократизаційних рухів у межах Арабської весни 2010 р. і водночас підтримка дружніх до США і пов’язаних з видобутком нафти авторитарних режимів у Саудівській Аравії, Тунісі, Бахрейні, Ємені ${ }^{18}$. Логіка геополітичного курсу Росії у даному відношенні виявилась у підтримці низки антиамериканських держав, таких як Іран, Венесуела, Сирія. У подальшому РФ і США - на протилежних позиціях щодо визначення сторін підтримки в подіях громадянської війни в Лівії (2011), боротьбі із сформованим терористичним утворенням ІДІЛ від 2015 р. в Іраку та Сирії.

Іншим, не менш важливим напрямом, що визначив серйозні протиріччя у позиціях американської і російської сторін, став контроль над ЗМЗ. Так, проголосивши курс на «перезавантаження», представники демократичної адміністрації Обами ініціювали тим самим переговорний процес з Росією з досягнення нової угоди про скорочення стратегічних наступальних озброєнь. Піковою точкою і одночасно найбільшим досягненням у цьому відношенні вважається підписання в Празі в квітні 2010 р. нової угоди між Сполученими Штатами та Російською Федерацією про стратегічні наступальні озброєння (CHO-3) та скорочення ракетно-ядерних арсеналів. На думку багатьох експертів, воно мало означати черговий етап перебудови світової архітектури безпеки ${ }^{19}$.

Втім, вже всередині 2010 р. в політиці «перезавантаження» у вимірі контролю над озброєннями намітилися проблеми, серед яких - відсутність компромісу щодо розміщення елементів американської ПРО в Європі, іранської програми збагачення урану, ядерних об’єктів Північної Кореї. Принципово відмінні позиції щодо цього стали підгрунтям не тільки загострення відносин сторін, а й поставили під сумнів можливість реалізації вже досягнутих результатів у зазначеній сфері.

Вагомого значення до того ж в аспекті накопичення суперечностей США і РФ в межах політики «перезавантаження» став курс Росії на перерозподіл на свою користь сфер впливу на пострадянському просторі після російсько-грузинського конфлікту 2008 р. «Війна підірвала тісні взаємовідносини, яких Сполучені Штати досягли 3 пост-радянськими країнами 3 моменту розвалу Радянського Союзу..., - пишуть американські аналітики А. Кохен і Р. Гамільтон. - Уже протягом двох років після російсько-грузинської стало зрозумілим, що конфлікт змінив баланс влади в пострадянській Євразії». Росія, як зазначають автори, продовжила зміцнювати своє домінування в регіоні. Вона, за даними, була задіяна в квітні 2010 р. до повалення діючої влади в Киргизстані. Серед напрямів політики - й тиск на Білорусь... У серпні

\footnotetext{
${ }_{16}$ Администрация Президента России. (2002, 24-26 мая)...

17 Слободян, Н. (2014). Антитерористична діяльність Сполучених Штатів Америки та Російської Федерації: порівняльний аналіз. Науковий вісник Дипломатичної Академії України при МЗС Украйни. Зовнішня політика і дипломатія: традииї, тренди, досвід. Серія «Історичні науки», 21 (I), 45-52.

18 Telata, G. (2014). Barack Obama, the War on Terrorism and the US Hegemony Alternatives. Turkish Journal of International relation, 13 (4), 50, 53-55.

19 Ялі, М. (2012). Вказ. пр., 47-54.
} 
2010 р. Москва розпочала торговельну війну проти Грузї і Молдови, примушуючи до цього своїх партнерів по Митному союзу, Казахстан і Білорусь... Сполучені Штати, по суті, втратили 20 років наполегливої політики щодо розвитку двосторонніх відносин в Євразії ${ }^{\circ}$.

Така ж ситуація постала по суті й перед іншими країнами пострадянського простору, включно з Україною, яка, після зміни керівництва в 2010 р., набула певних тенденцій дрейфу в бік Москви за умов посилення інтеграційних процесів у стратегічно важливих галузях. Втім саме зазначене стало поштовхом для Революції гідності як масштабного протестного вибуху в Україні, що, будучи орієнтованим на євроінтеграційні орієнтири та демократизацію країни стало не тільки причиною і приводом російської агресії з метою реалізації російських імперських планів, а й жорсткої (на противагу подіям у Грузії 2008 р.) реакції США на політику Москви. Агресія Росії стала по суті останньою ланкою критичної маси суперечностей, що повернули американську адміністрацію від стану холодного миру до стану холодної війни в російсько-американських відносинах та значно посилили увагу США до пострадянського простору (у більш широкому розумінні - східноєвропейського регіону) порівняно 3 попереднім періодом з іншими геополітичними пріоритетами (Близький Схід, АТР) адміністрації Обами.

Показово, що Україна відігравала в цьому відношенні не випадкову роль. Так, ще в другій половині 1990-х рр. в американській політичні думці сформувалась позиція про Україну як можливого провідника демократичних тенденцій та стабільності на пострадянському просторі та, за цим, необхідність підтримки їі цілісності ${ }^{21}$. Зазначене повторювало стверджений ще до того концептуальний підхід 3. Бжезинського про українську незалежність як ціннісний орієнтир зовнішньої політики Сполучених Штатів на противагу імперським зазіханням Росії 22.

Втім, в колі уваги дослідників нового покоління, й тенденція сприйняття російсько-українського збройного конфлікту у вимірі більш широкого геополітичного протистояння Росії і Заходу, коли агресія зміцнілої у військовому відношенні РФ проти України не обмежувалася виключно відновленням російських імперських впливів на пострадянському просторі, а була орієнтованою на глобальні процеси з відновленням статусу Росії в якості світового геополітичного («цивілізаційного») центру, здатного впливати і змінювати сталий світоустрій. Україна в межах такого підходу розглядалась як сфера зіткнення геоідей, геоекономіки або «критичної геополітики» двох полюсів, що базуються на протилежних цивілізаційних орієнтирах 23.

Так, Російська агресія проти України вочевидь змінила підходи США до РФ як провідного гравця пострадянського і загалом європейського простору. Якщо в Стратегії національної безпеки від 2010 р. демократичної адміністрації Обами Росія сприймалась як партнер, відповідний документ адміністрації від 2015 р. кваліфікував Росію в якості агресора, що потребує стримування 24.

Зазначені підходи знайшли подальше підтвердження й в стратегічних документах американської адміністрації президента Д. Трампа з ідеєю більш відвертого протистояння по лінії РФ - США Так, чинник агресії РФ на пострадянському просторі (на

${ }^{20}$ Cohen, A. \& Hamilton, R.E. (2011). The Russian Military and the Georgia war: Lessons and implications. Carlisle, Pennsylvania: Strategic Studies Institute.

${ }^{21}$ Zimmerman, W. (1998). Is Ukraine a Political Community? Communist and Post-Communist Studies, 31 (1), 44.

22 Brzezinski, Z. (1994). Premature Partnership. Foreign Affairs, 73 (2), 67-82.

23 Toal, G. (2017). Near Abroad: Putin, the West, and the Contest Over Ukraine and the Caucasus. Oxford: Oxford University Press; Charap, S. \& Colton, T.J. (2017). Everyone Loses: The Ukraine Crisis and the Ruinous Contest for Post-Soviet Eurasia. Routledge: The International Institute for Strategic Studies.

24 The White House. President Barack Obama. (2015, February). National Security Strategy. Retrieved from https://obamawhitehouse.archives.gov/sites/default/files/docs/ 2015_national_security_strategy_2.pdf 
прикладі Грузії й України) почав сприйматися американською стороною у вимірі загрози європейській стабільності та впливам Сполучених Штатів на Європейському континенті. В СНБ від 2017 р. за республіканську адміністрацію Д. Трампа з цього приводу стверджувалося про підривні заходи з боку Росії «для послаблення довіри до американської відданості Європі, підриву трансатлантичної єдності та послаблення європейських інститутів і урядів» 25.

Зазначене на грунті ядерного шантажу з боку РФ, у тому числі щодо країн ближнього зарубіжжя, а також фактичної ініціації Росією гонки озброєнь при порушенні Договору про ліквідацію ракет середньої і малої дальності - ДРСМД (та, насамкінець, заяви США і РФ про вихід з Договору в серпні 2019 р. ${ }^{26}$ ) окреслило по суті додатковий, надзвичайно серйозний виклик геополітичним впливам Сполучених Штатів. Відповідною щодо цього лінією з боку США можна вважати посилену увагу до країн, які зазнали агресії з боку Росії та готові протистояти РФ. Так, адміністрація Трампа фактично виявилася серед найбільш проукраїнських у сучасній історії США, що не тільки продовжила політику дипломатичної, військово-технічної допомоги Україні, а й схвалила рішення надання Києву оборонного озброєння, чого не спромоглися зробити за Б. Обами.

Втім, щодо самого Д. Трампа як чинного глави Білого дому, то його позиція (на противагу Б. Обами як активного від 2014 р. прихильника курсу на стримування РФ) не набула однозначної визначеності. По суті, визнаним $є$ превалювання конгресу у ствердженні й реалізації курсу, який характеризує сучасні відносини по лінії США - Росія або США - Україна. Так, у колі уваги аналітиків - вельми непрогнозовані за своїм характером висловлювання Д. Трампа - від можливості «домовитись» з РФ як тези початкового етапу президентства чинного глави держави до відновлення міжнародного статусу Росії (у форматі G-8) як заяв на самітах великої сімки у Ла-Мальбе (Канада, 2018 р.) і Біарріці (Франція, 2019 р.). Сутність останнього, за Трампом, - у доцільності повернення РФ до організації найбільш розвинених держав як спільної платформи обговорення світових проблем, щодо яких Росія виступає як «визначний гравець»27.

Як інтерпретують викладене аналітики, налагодження відносин з Росією без ніяких попередніх умов, за позицією Трампа, а саме - припинення агресії проти України (як причини виключення РФ з G-8), є по суті кроком щодо формування принципово нових підходів до взаємовідносин провідних міжнародних акторів, базованих на нівелюванні міжнародного права та інтересів середніх і малих держав. «Слова Дональда Трампа ... про повернення Росії в «Групу 7» - це анонс нового переформатування сил в міжнародних відносинах. New normal. Десь закладається новий порядок», - зазначав український дипломат і міжнародник Д. Лубківський ${ }^{28}$.

Саме це, як можна припустити, сформувало опозицію Трампу з боку більшості представників G-7 в Біарріці та, своєю чергою, з боку сенаторів-демократів в конгресі США29. Втім наміри представників американської адміністрації працювати над пове-

25 The White House. (2017, December). National Security Strategy of the Unites States of America. Retrieved from https://www.whitehouse.gov/wp-content/uploads/2017/12/NSS-Final-12-18-2017-0905.pdf ${ }_{26}^{6}$ Ядерный договор между США и Россией официально прекращает действие. (2019, 2 августа). $\quad$ Retrieved from https://censor.net.ua/news/3140891/ yadernyyi_dogovor_mejdu_ssha_i_rossieyi_ofitsialno_prekraschaet_deyistvie

27 У ЄС розповіли про труднощі обговорення ідеї Трампа повернути Росію до «Групи семи». (2019, 25 серпня). Retrieved from https://www.radiosvoboda.org/a/news-tramp-rosija-g7-g8samit/30128266.html.

28 Слова Макрона и Трампа о возвращении России в Группу Семи - это начало «нового порядка», - Лубкивский. (2019, 21 августа). Retrieved from https://censor.net.ua/news/314406o/ slova_makrona_i_trampa_o_vozvraschenii_rossii_v_gruppu_semi_eto_nachalo_novogo_poryadk a_lubkivskiyi

29 У ЄС розповіли про труднощі обговорення ідеї Трампа повернути Росію до «Групи семи»..; Trump Wants Russia Back in the G-7, But Several Senators Say It Doesn't Belong. (2019, August 27). Retrieved from https://www.npr.org/2019/08/27/754811266/trump-wants-russia-back-in-the-g7but-several-senators-say-it-doesnt-belong 
рненням Росії в G-7, як про це заявив держсекретар США М. Помпео30, можуть мати насамкінець неочікувані негативні реалії з посиленням міжнародного статусу Росії, а за цим - перерозподілу геополітичних впливів на корить останньої як на регіональному, так і світовому рівні.

Висновки. Якщо підійти, з урахуванням вищевикладеного, до визначення перспектив взаємовідносин по лінії США - Росія, то стабілізація відносин сторін передбачає повагу з боку Росії до норм міжнародного права, ліберальних цінностей, що сформували від початку 1990-х рр. курс США на підтримку нових демократій та, своєю чергою, визначили євроінтеграційні орієнтири низки країн, зокрема, Грузії і України. Так, реалізація імперських тенденцій з боку РФ об’єктивно зумовлюватиме протистояння сторін, коли стримування РФ залишиться найбільш ймовірною лінією міжнародної лінії поведінки Сполучених Штатів на європейському і світовому рівні. Альтернатива цьому - за умов сповзання адміністрації США до міжнародних (безпекових) поступок Росії не виключає звуження можливостей впливати на процеси, які безпосередньо стосуються світових орієнтирів Сполучених Штатів. Водночас прагматизм підходу до міжнародної політики вимагає послідовної підтримки демократичних суспільств на противагу агресії з боку Росії, що сприймається не тільки у вимірі послабленню міжнародно-політичних й економічних позицій агресора, а й сприяння стратегічних орієнтирів у системі безпекових й економічних інтересів самих США.

\section{REFERENCES}

Administratsiia Prezidenta Rossii. (2002, 24-26 maia). Sovmestnaia deklaratsiia Prezidenta $V V$ Putina i Prezidenta Dzh Busha o novykh strategicheskikh otnosheniiakh mezhdu Rossiiskoi Federatsiei i Soedinennymi Shtatami Ameriki. [Joint Declaration by President Vladimir Putin and President J. Bush on new strategic relations between the Russian Federation and the United States of America]. Retrieved from http://www.president.kremlin.ru/summit 8/s8-doc.2ru.html [in Russian].

Brzezinski, Z. (1994). Premature Partnership. Foreign Affairs, 73 (2), 67-82. [in English]

Charap, S. \& Colton, T.J. (2017). Everyone Loses: The Ukraine Crisis and the Ruinous Contest for Post-Soviet Eurasia. Routledge: The International Institute for Strategic Studies. [in English]

Cohen, A. \& Hamilton, R.E. (2011). The Russian Military and the Georgia war: Lessons and implications. Carlisle, Pennsylvania: Strategic Studies Institute. [in English]

Cornell, S.F. (2002). America in Eurasia: One Year After. Current History. A Journal of Contemporary World Affairs, 101 (657), 330-336. [in English]

Dzekish, J. (2019, August 27). Pompeo promised to tackle the return of Russia to G7. Retrieved from https://www.diplomacy24.com/pompeo-promised-to-tackle-the-return-of-russia-to-theg7/ [in English]

Hearing before the Committee on International Relations. House of Representatives, 105-th. Congress, 1-st session. (1997, March 12). US Relations with Russia and the Newly Independent States. Washington: Gov. print. off. [in English]

Hoffman, D. (1991, December 9). «Soviet Union as we've known it» is gone, Baker says. The Washington Post. [in English]

Interviu Dzh Busha gruppe zhurnalistov v Belom dome. (2001, 14 iiunia). «Rossiia ne iavliaetsia vragom SSHA». [«Russia is not an enemy for Russia»]. Retrieved from http://news.bbc.co.uk/hi/russian/news.sid-138800o/1388695 [in Russian]

Luers, W.H. (1992). Harmonizing U.S. and European Interests. In I.J. Lederer (Ed.), Western Approaches to Eastern Europe (pp. 16-44). New York: Council on Foreign Relations Press. [in English]

Lynch, A. (1992). The Cold War is Over-Again. Boulder, San Francisco, Oxford: Westview Press. [in English]

Maynes, Ch.W. (2003). America Discovers Central Asia. Foreign Affairs, 82 (2), 120-132. [in English]

Meyer, S.M. (1991, December 12). Hyping the Soviet Nuclear Peril. New York Times. [in English]

Motyl, A.J. (1991). Totalitarian Collapse, Imperial Disintegration, and the Rise of the Soviet West: Implications for the West. In A.J. Motyl (Ed.), The Rise of Nations in the Soviet Union. American Foreign Policy and the Disintegration of the USSR (pp. 44-63). New York: Council of Foreign Relations Press [in English]

$3^{\circ}$ Dzekish, J. (2019, August 27). Pompeo promised to tackle the return of Russia to G7. Retrieved from https://www.diplomacy24.com/pompeo-promised-to-tackle-the-return-of-russia-to-the-g7/ 
National Security Strategy Archive. (2010, May 27). National Security Strategy. Retrieved from http://nssarchive.us/national-security-strategy-2010/ [in English]

Natsionalnyi instytut stratehichnykh doslidzhen. (2008, 14 serpnia). Ekspertna dyskusiia «Rosiiskohruzynskyi konflikt: prychyny ta naslidky dlia yevropeiskoi bezpeky». [Expert Discussion «The Russian-Georgian conflict: Causes and consequences for European security»]. Retrieved from http://old.niss.gov.ua/Table/1408008/stenograma.htm [in Ukrainian].

Newmann, W.W. (1993). History Accelerates: The Diplomacy of Cooperation and Fragmentation. In J.E. Goodby, \& B. Morel (Eds.), The Limited Partnership. Building a Russian-US Security Community (pp. 28-54). Oxford: Oxford University Press. [in English]

Rice, C. (2000). Life after the Cold War. Campaign 2000: Promoting the National Interest. Foreign Affairs, 79 (1), 45-62. Retrieved from https://www.foreignaffairs.com/articles/2000-01o1/campaign-2000-promoting-national-interest [in English]

Slobodian, N. (2014). Antyterorystychna diialnist Spoluchenykh Shtativ Ameryky ta Rosiiskoi Federatsii: porivnialnyi analiz. [Anti-terrorist activity of the United States of America and the Russian Federation: a comparative analysis]. Naukovyi visnyk Dyplomatychnoi Akademii Ukrainy pry MZS Ukrainy. Zovnishnia polityka i dyplomatiia: tradytsii, trendy, dosvid. Seriia «Istorychni nauky», 21 (I), 45-52. [in Ukrainian]

Slova Makrona i Trampa o vozvrashchenii Rossii v Gruppu Semi - eto nachalo «novogo poriadka», Lubkivskii. (2019, 21 avgusta). [Macron and Trump's words about Russia's return to the Group of Seven are the beginning of a «new order», - Lubkivskii]. Retrieved from https://censor.net.ua/news/314406o/slova_makrona_i_trampa_o_vozvraschenii_rossii_v_ gruppu_semi_eto_nachalo_novogo_poryadka_lubkivskiyi [in Russian].

Telata, G. (2014). Barack Obama, the War on Terrorism and the US Hegemony Alternatives. Turkish Journal of International relation, 13 (4), 41-58. [in English]

The White House. President Barack Obama. (2015, February). National Security Strategy. Retrieved from https://obamawhitehouse.archives.gov/sites/default/files/docs/2015_national_security_ strategy_2.pdf [in English]

The White House. (2017, December). National Security Strategy of the Unites States of America. Retrieved from https://www.whitehouse.gov/wp-content/uploads/2017/12/NSS-Final-12-182017-0905.pdf [in English]

Toal, G. (2017). Near Abroad: Putin, the West, and the Contest Over Ukraine and the Caucasus. Oxford: Oxford University Press. [in English]

Trump Wants Russia Back in the G-7, But Several Senators Say It Doesn't Belong. (2019, August 27). Retrieved from https://www.npr.org/2019/o8/27/754811266/trump-wants-russia-back-in-theg7-but-several-senators-say-it-doesnt-belong [in English]

U YeS rozpovily pro trudnoshchi obhovorennia idei Trampa povernuty Rosiiu do «Hrupy semy». (2019, 25 serpnia). [It is told in EU about the difficulties of discussing the idea of Trump to return Russia to the «Group of Seven»]. Retrieved from https://www.radiosvoboda.org/a/news-tramprosija-g7-g8-samit/30128266.html [in Ukrainian].

Yadernyi dogovor mezhdu SShA i Rossiei ofitsialno prekrashchaet deistvie Ядерный договор между США и Россией официально прекращает действие. (2019, 2 avgusta). [U.S.-Russia nuclear deal officially terminates]. Retrieved from https://censor.net.ua/news/3140891/ yadernyyi_dogovor_mejdu_ssha_i_rossieyi_ofitsialno_prekraschaet_deyistvie [in Russian].

Yali, M. (2012). Rosiisko-amerykanski vzaiemovidnosyny naperedodni prezydentskykh vyboriv v RF: pidsumky "perezavantazhennia». [Russian-American relations on the eve of the presidential elections in the Russian Federation: results of «Reload»]. Aktualni problemy mizhnarodnykh vidnosyn, 107 (II), 47-54 [in Ukrainian].

Zimmerman, W. (1998). Is Ukraine a Political Community? Communist and Post-Communist Studies, 31 (1), 44. [in English]

Iryna Dudko,

National Academy for Public Administration under the President of Ukraine ORCID: https://orcid.org/oooo-0oo2-8881-8274

\section{Russia in the context of foreign policy strategy of the USA: political and descriptive analysis of the post-bipolar times}

The article is focused on the political and descriptive analysis of the U.S. foreign policy towards Russia under the post-bipolar times. Among the problems under discussion are the factors which caused special attention of the American leadership to Russia from the 
beginning of the post-bipolar world, as well as the evolution of the US strategic approaches to Russia during 1990-2010-s years, including military aggression of Russia against Georgia (2008) and Ukraine (2014-2020).

Authoress applies to commonly acknowledged position that Russia as a great state will always be in the circle of the USA interests. This approach is based on the status of Russia as a nuclear power state and a member of the UN Security Council, which, despite difficulties of its internal development, maintains impact upon international relations. However, it is Russia's influence on international relations that constitutes by reflecting imperial claims a threat to the world status quo, contrary to the position of the United States, and thus causes a line of rivalry between the parties.

The paper is tracing the process of accumulation contradictions in the US-Russian relations, which led from the partnership to the state of a new Cold War between the parties. It is deliberated the problematical character of the American administration's reaction to Russia's aggression against and Georgia (2008) and, in turn, the sharpness of the USA's reaction to the Russian-Ukrainian armed conflict in 2014. It Is noted that Ukrainian factor - according to rivalries of RF and the USA - had overcome the postSoviet space, but acquired a civilization nature. So, an aid to Ukraine from the USA in this respect has got an objective character regarding not only American national interests, but Western liberal values and freedoms.

Keywords: USA foreign policy strategy, Russia, rivalries 